\title{
Rice yellow mottle virus Is Transmitted by Cows, Donkeys, and Grass Rats in Irrigated Rice Crops
}

\author{
Soungalo Sarra, Programme Riz Irrigué, Institut d'Economie Rurale, BP 12, Niono, Mali; and Dick Peters, \\ Laboratory of Virology, Wageningen University, Binnenhaven 11, 6709 PD Wageningen, The Netherlands
}

\begin{abstract}
Sarra, S., and Peters, D. 2003. Rice yellow mottle virus is transmitted by cows, donkeys, and grass rats in irrigated rice crops. Plant Dis. 87:804-808.

Rice yellow mottle virus (RYMV), endemic in Africa, is believed to be spread by chrysomelid beetles, although the infections in a field often cannot be explained by the prevailing number of beetles. We show that the grass rat Arvicanthis niloticus, domestic cows (Bos spp.), and donkeys (Asinus spp.) are potent and efficient transmitters of RYMV. Spread of RYMV by rats was demonstrated in cage experiments wherein individual rats transmitted the virus from healthy to infected rice plants and confirmed in a field experiment. Experiments with cows and donkeys showed that they could transmit the virus in plots with healthy and infected plants and to plots with healthy plants. A high percentage of seedlings became infected when a cow grazed in a seedbed after being fed with infected rice plants. Transmission also was observed when cows were allowed to graze on the stubble of infected fields. The disease incidence increased at least fourfold over time to approximately $36 \%$ of the plants infected in the experimental plots of two stubble fields. The results obtained in these stubble fields suggest that cattle-mediated spread will enhance the size of the virus load in the contraseason and the infection potential to infect the next crop.
\end{abstract}

Additional keywords: Chrysomelids, epidemiology, RYMV transmission

Rice yellow mottle virus (RYMV), a member of the family Sobemoviridae, was first described in the 1960s in Kenya (4). This virus is endemic in Africa, south of the Sahara, and occurs mainly in irrigated rice ecosystems. RYMV has been reported from several East, Central, and West African countries, including the islands of Zanzibar and Madagascar $(1,5,6,18,21,22)$. The virus infects most, if not all, wild rice species (Oryza spp.) and several grass species $(3,5,9)$. The wild rice species $O$. longistaminata A. Chev. et Roerh. is believed to be a natural virus source in the Soudano-sahelian zone. The virus also may be spread from infected plants of $O$. barthii A. Chev. and the grass species Echinochloa colona L. Link, Panicum repens L., and Ischaemum rugosum Salisb. (16).

RYMV induces a variety of symptoms on rice plants. They include mottling, yellow or orange leaf discoloration, reduced tillering, stunting of plants, and sterility of

Corresponding author: D. Peters

E-mail: dick.peters@wur.nl

This research was supported by a fellowship to $\mathrm{S}$. Soungalo of the Netherlands Foundation for the Advancement of Tropical Research (WOTRO, project WB 83-175).

Accepted for publication 1 February 2003.

Publication no. D-2003-0417-01R

(C) 2003 The American Phytopathological Society flowers $(2,5)$. This sterility affects the yield of the crops considerably when the plants become infected early in their development. Occasionally, severe yield losses, up to 84 to $97 \%$, have been recorded for different crops $(12,14,15,24)$. Most, if not all, commercial rice cultivars are susceptible to the virus, although their susceptibility varies considerably (11).

Like all sobemoviruses, RYMV is readily transmitted mechanically. Moreover, several beetle species belonging to the family Chrysomelidae have been shown to transmit this virus $(5,7,21)$. Of these beetles, Trichispa sericea is the most frequently encountered beetle in rice crops and is known as a serious pest on rice in Africa. However, no studies have been made on the significance of this beetle in the spread and epidemics of RYMV in crops, or of any other beetle species described as vector.

The low number of beetles often actually caught in fields in the Soudano-sahelian region and the different patterns of virus spread found in various fields strongly suggest that RYMV is not spread only by beetle-mediated transmission $(13,19,20,23)$. Crops of most farmers in the region of "Office du Niger", the largest rice-cropping area in Africa, are completely or apparently healthy, whereas infections can be found in crops of a relatively low number of farmers. Completely infected fields may directly neighbor fields in which no infections can be discerned.
Infection in most affected crops varies from a single infected plant to numerous patches with infected plants; infected patches vary in size from 1 to $20 \mathrm{~m}$ in diameter, or more, in a field. In addition to these patches, short to long strips of infected plants can occur along the levees of the rice fields, the roadsides, or at the corner of a road and a levee of a field. The clustered appearance of infected plants in these strips and at corners does not support a beetle-mediated spread of the virus from infected grass and wild rice plants on the levees and roadsides. A more scattered spread can be expected when beetles are the sole transmitters. This observation and the occurrence of completely infected fields next to fields without any infected plant suggests that the virus also spreads by factors other than beetles.

During the growing season, numerous rats of the species Arvicanthis niloticus live in burrows on the levees and roadsides surrounding the paddy rice fields. The association of feeding damage to plants and the presence of rat roads and droppings with the occurrence of infected plants suggests that rats can cause the infections along the levees and roadsides and at corners. In this article, we present evidence that RYMV is spread by this grass rat species.

Sheep also can transmit sobemoviruses by grazing and trampling, as shown by the spread of Subterranean clover mottle virus (SCMoV) in subterranean clover $(10,17)$. Cattle and donkeys occasionally graze on seedlings in seedbeds, and cattle feed on rice stubble in harvested fields in the Soudano-sahelian zone; therefore, we studied the potential of cattle and donkeys to transmit RYMV. This hypothesis was tested in several experiments, in which cows and donkeys were allowed to graze partially infected experimental plots and cows could graze healthy seedbeds after ingesting infected rice plants and partially infected stubble fields. The significance of the transmission of this virus by these mammals will be discussed with respect to the spread and survival of RYMV in the field.

\section{MATERIALS AND METHODS}

Transmission and spread of RYMV by the grass rat $A$. niloticus. Four male and two female rats were caught after covering their burrows by a net and pouring water into the entrances. The 
caught rats were individually placed with 15 healthy plants of the highly susceptible rice cv. BG 90-2 interspersed with five RYMV-infected plants in 2-by-2-m cages for $9 \mathrm{~h}$. A seventh cage without a rat, but with the same number of healthy and infected plants, served as a check to monitor any other type of natural virus spread (e.g., by beetles). All cages were enclosed within a screenhouse and sprayed weekly to control insects. The plants were visually inspected for infection 3 weeks later and tested by enzyme-linked immunosorbent assay (ELISA).

Spread of RYMV by the grass rat in the field. Spread in the field was studied in an experiment wherein rats had free access to rice plants at only one side of a levee. This levee, 40-cm wide, separated two fields ( $\mathrm{A}$ and $\mathrm{B}$ ) containing the rice $\mathrm{cv}$. BG 90-2. The soil sloped slightly upward to the levee in field A. This slope gave the rats access to the plants depending on the water level. The soil in field B did not slope, so that the plants next to the levee grew in a water layer varying between 15 and $20 \mathrm{~cm}$ deep, by which the rats had no access to the plants. The presence of several rat burrows, as judged by the presence of fresh entrances, showed that rats were living on the levee and along the 100-cm-wide dike bordering both fields at one side. A few infected specimens of susceptible wild grass species and $O$. longistaminata (a natural source of RYMV) grew on this levee and the dike. Virus incidence in field $\mathrm{A}$ and $\mathrm{B}$ was recorded in three blocks $4 \mathrm{~m}$ long and 0.7 $\mathrm{m}$ wide. These blocks had their center at a 15,45 , and $75 \mathrm{~m}$ of the $90-\mathrm{m}$ long levee.

Transmission of RYMV by cows and donkeys. Cattle-mediated spread of RYMV was studied during the growing season of 2000. Seed of the rice cv. BG 902 were sown directly at a distance of 25 by $-25 \mathrm{~cm}$ in two plots of $11 \mathrm{~m}^{2}$ each with 162 plants. Fifteen days after sowing, 10 seedlings were inoculated mechanically in the first plot (A) using an extract of $1 \mathrm{~g}$ of infected plant material in $10 \mathrm{ml}$ of $0.01 \mathrm{M}$ phosphate buffer, $\mathrm{pH}$ 7.2. The inoculated plants were distributed randomly in the plot and their position marked. No plants were inoculated in the second plot (B). When symptoms (15 days after inoculation) appeared, a 1-year-old calf grazed plot $\mathrm{A}$ for $1 \mathrm{~h}$, and then was transferred to plot $\mathrm{B}$ for $4 \mathrm{~h}$ to demonstrate that the virus could be spread to a new plot after grazing a plot with infected plants. Disease incidence was monitored visually and by ELISA 3 and 6 weeks post roaming and grazing. After the last monitoring, the calf again was given free access to both plots for $10 \mathrm{~h}$ and the disease incidence monitored at 3 and 6 weeks after the second visit. A third plot (C), with 112 plants, was used to monitor any natural spread.

Donkey-mediated transmission was studied in a similar experiment. Plots A, B, and C contained 191, 143, and 60 plants, respectively. The donkey finished plot $\mathrm{A}$ in 25 min and then was transferred to plot B, which was grazed in $30 \mathrm{~min}$. This donkey again was given access to both plots following monitoring the infection 6 weeks after the first visit.

Cow-mediated transmission of RYMV to a seedbed. To study the probability that cattle can infect seedlings in a seedbed, each of two seedbeds were sown with approximately 1,200 seeds of the rice $\mathrm{cv}$. BG90-2 and 20 seeds in four buckets. The seedlings of two buckets were inoculated with RYMV. Three weeks later, the noninoculated seedlings were fed to a cow, which then was allowed to graze one of the seedbeds. A day later, this cow was allowed to graze the second seedbed after ingesting the infected seedlings. One thousand seedlings were transplanted from each seedbed in the field 2 weeks after grazing. Disease incidence was monitored visually every 2 days starting 6 days after transplanting.

Spread of RYMV by cows in stubble fields. To study the spread of the virus to rice stubble, a field experiment was designed after the harvest in two partially infected rice crops. In the first field (field 1), 25 plots of $1 \mathrm{~m}^{2}$, scattered over the field, were selected randomly. The total number of plants in these plots ranged between 12 and 31, of which the number of infected plants ranged between 1 and 6 . In the second field (field 2) 72 plots, each with 10 to 30 plants, were selected, among which 52 were not infected. The number of infected plants varied from 1 to 9 in the 20 infected plots. The location of the plots was mapped and the infected plants labeled. Seven cows roamed and grazed for 9 $\mathrm{h}$ in field 1 , and 15 cows for $4 \mathrm{~h}$ in field 2 . RYMV infection and rat damage was checked in the plots of both fields every 2 weeks by counting the number of stubble with infected regrowth without entering the plots. Ten $1 \mathrm{~m}^{2}$ plots were surrounded by a barbed wire fence and served as a control in each field.

Insect infestation. The insect population was monitored in the stubble fields wherein the spread of the virus was studied by cattle. One hundred catches were made with a butterfly net at 15,30 , and 45 days post grazing to trap insects in each field. Insects trapped were brought for identification to Y. Jongsma at the Laboratory of Entomology, Wageningen University, Wageningen.

ELISA. The infected plants of cv. BG90-2 produce pronounced symptoms; therefore, most surveys were made visually on leaves or on young developing sprouts. ELISA was used to demonstrate infection in those cases where doubtful symptoms appeared on the leaves or sprouts and when small numbers of plants were used. The ELISA procedure originally described by Clark and Adams (8) was essentially followed. The wells of the plates were incubated with $0.1 \mathrm{ml}$ of immunoglobulin $\mathrm{G}$ sample $(0.1 \mu \mathrm{g} / \mathrm{ml})$, conjugate $(0.1$ $\mu \mathrm{g} / \mathrm{ml})$, or substrate $(1 \mathrm{mg} / \mathrm{ml})$ in the respective incubation steps for $2 \mathrm{~h}$ at room temperature. The antiserum used was produced against a virus preparation purified from infected BG 90-2 plants according to a procedure described by Fauquet and Thouvenel (9). Samples were prepared by grinding leaf material in a weight:volume ratio of $1: 10$ with sample buffer containing $0.05 \%$ Triton 20 .

\section{RESULTS}

Rat-mediated transmission of RYMV. Stems and leaves of the rice plants, felled by gnawing, were observed in the cages with males. Some of the felled stems were even cut in large pieces. This damage was characteristic for the type of damage found in the field at spots along levees and roadsides and at corners where infections often occurred. Of the 15 healthy plants, 10 to 14 became infected in the respective cages with males (Table 1). No infected plants were found in the cages with females, although one plant was damaged in one cage, and in the control cage. Instead of feeding on the offered plants, the female rats were searching for ways to escape from the cages or were sitting in the darkest corner. Disease symptoms were observed within 20 days post exposure to the rats and did not increase in the 25 following days. Some damaged plants did not develop disease symptoms and did not give a positive response in ELISA. The healthy plant damaged by a female rat did not develop symptoms and was negative in ELISA. The absence of any spread in the cages with female rats and the control cage also demonstrates that spread of the virus by beetles or any other alternative

Table 1. Transmission of Rice yellow mottle virus to BG 90-2 plants by individual grass rats of the species Arvicanthis niloticus placed in cages with 15 healthy and 5 infected plants

\begin{tabular}{lccc}
\hline & \multicolumn{3}{c}{ Number of plants } \\
\cline { 2 - 4 } Rat & Damaged/cage & Damaged but not infected & Infected \\
\hline Male 1 & 19 & 1 & 14 \\
Male 2 & 20 & 1 & 13 \\
Male 3 & 17 & 3 & 10 \\
Male 4 & 20 & 0 & 14 \\
Female 1 & 0 & 0 & 0 \\
Female 2 & 1 & 1 & 0 \\
Control & 0 & 0 & 0 \\
\hline
\end{tabular}


vector or mechanism could be excluded in this experiment.

Spread of RYMV by rats in the field. The first infected plants were observed 3 weeks after transplanting the seedlings at the levee side A, where the rats had access to the plants. This spread coincided with the presence of rat roads on the soil, severe plant damage, felled plant remains, and plants with truncated stems. The felled leaves and stems occasionally formed a rats could move from plant to plant. The initial infections were noticed in the first row of plants along the levee, and extended to the second and third row and occasionally to the fourth row during the growing season. Almost all of the plants in the first row were infected over the whole length of the levee. The infected plants varied from 64 to $77 \%$ in the three blocks sampled at levee side A (Table 2). Virusinfected rice plants could not be discerned at the other side of the levee (B), where the water level prevented the rats from feeding on the plants (Table 2). The poaceous flora, consisting of $O$. longistaminata and grass species on this levee, appeared to be 43 and $17 \%$ infected by RYMV when 60 and 30 plants were tested for infection by ELISA, respectively.

Transmission of RYMV by cattle and donkeys. All plants in plot A and B were almost completely eaten by the calf during the first grazing in the virus-infected (A) and noninoculated plot (B). In plot A, 46 plants $(29 \%)$ became infected; whereas, in plot B, 16 plants (10\%) became infected (Table 3). The infected plants in plot A were almost randomly distributed over the whole plot, whereas most of the plants in plot B became infected in that part where the first plants were eaten. These results show that cattle are able to transmit RYMV by grazing and that the virus bridge between some plants by which the

substantially can be spread from the infected plot to the healthy one. In the second round of grazing, another 89 plants became infected in plot A and 39 in plot B (Table 3).

A donkey also transmitted RYMV in a similar experiment when released in an infected (A) and, subsequently, in a noninfected (B) plot. The donkey, remarkably, ate the plants row by row. The first infected plant was the fourth in the first grazed row. The third plant eaten was the first inoculated plant in this row. The virus was transmitted to 99 plants in plot A and 51 plants in plot $\mathrm{B}$ during the first grazing, and an additional 88 plants became infected in plot A and 26 in plot B in the second round of grazing 6 weeks later (Table 3). Infected plants were not found in either control plot (C). The absence of any infection suggested that neither beetles nor any other alternative vector were responsible for the RYMV transmission in the grazed plots.

Seedbed infection by cattle. Of the 1,000 seedlings transplanted from the seedbed that was grazed by the cow after eating 10 RYMV infected seedlings, 43\% became infected (Fig. 1). None of the 1,000 seedlings of the seedbed in which the cow grazed after eating 10 noninoculated seedlings became infected.

Spread of RYMV by cattle in the field. The spread of RYMV by cattle was confirmed in stubble fields that were partially infected. Before the cattle roamed the fields, the average disease incidence in the selected plots was $9 \%$ in field 1 and $4 \%$ in field 2 (Table 4). Fifteen days after grazing, the percentage of infected plants increased to $20 \%$ in field 1 and $6 \%$ in field 2 (Table 4). At 30 and 45 days after the cattle visited these fields, the infection increased to an average of 29 and $36 \%$ in field 1 and 14 and $21 \%$ in field 2 , respectively. The

Table 2. Transmission of Rice yellow mottle virus by the grass rat Arvicanthis niloticus in two fields along a levee ${ }^{\mathrm{a}}$

\begin{tabular}{|c|c|c|c|c|c|c|}
\hline \multirow[b]{2}{*}{ Block } & \multicolumn{2}{|c|}{ Number of tufts sampled } & \multicolumn{2}{|c|}{ Number of infected tufts } & \multicolumn{2}{|c|}{ Incidence $(\%)$} \\
\hline & $\mathbf{A}$ & B & $\mathbf{A}$ & B & $\mathbf{A}$ & B \\
\hline 1 & 526 & 560 & 334 & 0 & 63.5 & 0 \\
\hline 2 & 546 & 743 & 360 & 0 & 65.9 & 0 \\
\hline 3 & 883 & 689 & 678 & 0 & 76.8 & 0 \\
\hline
\end{tabular}

${ }^{a}$ Rats had access to the plants on side A of the levee but not to the plants on side B. Plants were sampled for infection in blocks $4 \mathrm{~m}$ long and $0.7 \mathrm{~m}$ wide at 15,45 , and $75 \mathrm{~m}$ of the $90-\mathrm{m}$-long levee. number of infected plots increased from 20 to 63 in field 2. This increase has to be explained by transmission of the virus by the cattle from infected plants present in the direct surroundings of the healthy plots. Transmission by rats could be excluded because no damage was observed in the plots. The incidence of RYMV infection did not increase in control plots, because cattle had no access to them.

Insect population. The prevailing insect population in the stubble fields wherein cattle had grazed was determined 15, 30, and 45 days post grazing. The number of insects caught was extremely low and consisted of members of Dipterae, Coleopterae, and Homopterae. A few members of the Hymenopterae, Heteropterae, Odonate, Orthopterae, and Arachnidae (spiders) were found in the catches made in fields 1 and 2 (Table 5). None of the beetle species reported to be RYMV vectors or any other chrysomelid beetle species were found in these catches.

\section{DISCUSSION}

Most plant viruses are transmitted from plant to plant by invertebrate feeding. Vertebrates also can transmit plant viruses by feeding, as shown for RYMV in this study. The grass rat $A$. niloticus efficiently transmitted RYMV to healthy rice plants after gnawing and feeding on infected-plants. Out of the 60 plants exposed for $9 \mathrm{~h}$ to four male rats, 51 plants became infected (Table 1). None of the plants became infected in the cages where the plants were exposed to female rats or in the control plot. The absence of any infected plant in the cages with the females cannot be explained by an incapability to transmit, but by their different behavior in captivity. They showed severe signs of stress, such as searching for ways to escape from the cages, or sat in the outmost corner. This rat species lives, preferably, on cultivated rice plants; therefore, females, like the males, will also transmit RYMV in the field.

The spread of RYMV by rats was confirmed in the field. Infected plants were detected only at that side of a levee where rats had access to plants (Table 2). Where the rats could not feed on plants because access was prevented by water, no infection was observed.

Slopes, which give rats access to plants, often are found along the levees and road-

Table 3. Number of Rice yellow mottle virus (RYMV) infected plants by either a calf or a donkey grazing first in plot A with infected plants and then in plot B with only healthy plants, and 6 weeks later in both plots

\begin{tabular}{|c|c|c|c|c|c|c|}
\hline \multirow[b]{3}{*}{ Plot } & \multicolumn{6}{|c|}{ Number of plants infected with RYMV following grazing by ${ }^{a}$} \\
\hline & \multicolumn{3}{|c|}{ Calf } & \multicolumn{3}{|c|}{ Donkey } \\
\hline & $\mathbf{A}$ & B & $\mathbf{C}$ & $\mathbf{A}$ & B & $\mathbf{C}$ \\
\hline Total number of plants & 162 & 162 & 112 & 191 & 143 & 60 \\
\hline Before grazing & 10 & $\ldots=0$ & $\ldots=0$ & 10 & $\ldots=0$ & $\ldots=0$ \\
\hline After first grazing & $46(29)$ & $16(10)$ & 0 & $99(52)$ & $51(36)$ & 0 \\
\hline After second grazing & $89(55)$ & $39(24)$ & 0 & $188(98)$ & $77(54)$ & 0 \\
\hline
\end{tabular}

${ }^{\mathrm{a}} \mathrm{C}=$ control, and number in parentheses = percent infected plants. 
sides around a field. Plants at such positions often are infected and usually occur in a closed formation of plants. The frequent presence of infected plants at corners of rice fields also can be explained by sloping of the soil at corners. Inspection of corners with infected plants showed that they often coincided with the presence of rat roads on the soil, plants of which the stems and leaves are felled, and plant remains and debris of the felled stem and leaves. Rat burrows were not always found at or close to the spots with infected plants, but were readily detected in the neighborhood.

The first plants infected by rats were usually the result of a new virus introduction in a field. The source has to be sought in the natural vegetation on the levees and roadsides. Plants of the wild rice species O. longistaminata growing on the levees are probably the main source of infection. Plants of this species maintain themselves through rootstocks and will, when infected, continuously produce new infected sprouts. Control of this species and other susceptible grass species will be one of the main objectives in the control of this virus.

In the rice-growing season, rats live on the levees, roadsides, and other dry places. In the off season, however, rats live in the harvested fields, where they have access not only to spilled grains but also to green sprouts of the stubble. The damage observed on the green sprouts makes it likely that transmission also will occur between the sprouts of infected and healthy stubble. We made no studies to quantify this spread.

Cows and donkeys also were effective transmitters of RYMV. The number of infected plants increased 5- to 10-fold after a calf or a donkey was given access to the plots with the infected plants (Table 3). Moreover, having grazed the infected plots, the calf and the donkey were able to infect 16 or $51 \%$ of the plants, respectively, in the second plot, which consisted initially of healthy plants only. These results indicate that cattle and donkeys can transmit the virus to plants over some distance and that a substantial number of plants can be eaten before the saliva does not contain any more virus to infect plants. The donkey had eaten at least 138 plants in the first round in plot B before infecting the last plant. Hence, it can be concluded that this donkey infected 60 plants out of 138 plants eaten in the second plot with the virus acquired in the first plot. These observations show that the donkey has a large capacity to infect plants after acquisition of the virus from infected plants and that it is a more efficient transmitter than the calf, which transmitted RYMV to only 16 out of 162 plants in plot $B$ in the first visit. Mechanisms of spread in the experimental plots others than those described have to be ruled out because no infections were found in the control plots.

Transmission of RYMV by rats, cattle, and donkeys might suggest that other mammals are also transmitters of RYMV. The first mammals that come to mind are

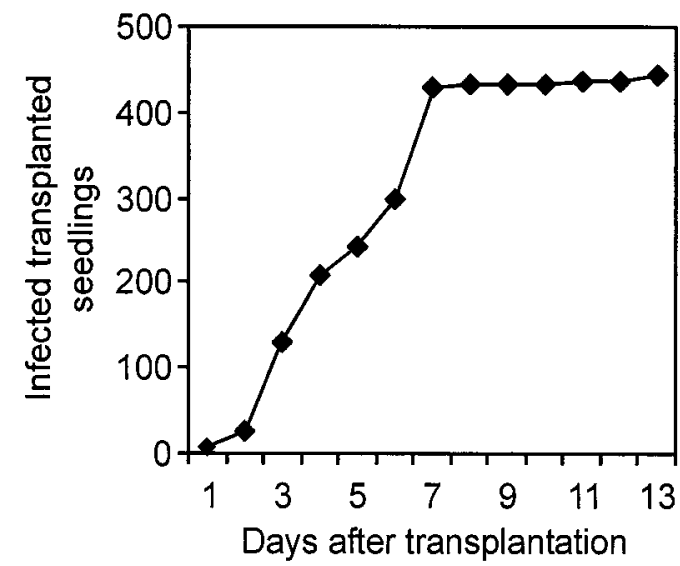

Fig. 1. In a seedbed with approximately 1,200 seedlings, number of seedlings that became infected after grazing by a cow that had been fed with 10 Rice yellow mottle virus-infected rice plants. One thousand seedlings were transplanted and monitored for infection.

Table 4. Mean increase (\%) of Rice yellow mottle virus (RYMV)-infected plants in two partially infected fields after being grazed by cattle

\begin{tabular}{lccccc}
\hline & & \multicolumn{4}{c}{ Average RYMV incidence (\%) before and after grazing } \\
\cline { 3 - 6 } Field & Plants/plot $^{\text {a }}$ & Before & 15 days after & 30 days after & 45 days after \\
\hline 1 & 24 & 9 & 20 & 29 & 36 \\
Control (1) & 10 & 8 & 8 & 9 & 9 \\
2 & 19 & 4 & 6 & 14 & 21 \\
Control (2) & 10 & 4 & 4 & 4 & 4 \\
\hline
\end{tabular}

${ }^{a}$ Average number of plants per plot. sheep and goats that also often can be encountered on the roads between the rice fields in the Soudan-sahelian zone. However, due the texture of these plants, they do not prefer to eat rice plants. This may indicate that the potential of these mammals to spread RYMV will be low or negligible.

Rats, cattle, and donkeys infect plants at spots on roadsides where they have access to rice plants. Infection by rats can be distinguished easily from infection by cattle and donkeys. The latter progressively decapitate the plant from top to bottom, whereas rats fell the plant and leave the felled stem and leaves.

Trampling plants also is considered to be a mechanism by which sheep could spread SCMoV $(10,17)$. This type of spread may be the result of creating wounds on the roots, release of virus, and subsequent infection of the roots of healthy plants. This spread can be excluded in our experiments when the calf and donkey grazed plot B in the first round, but not when the calf and donkey had access to the infected plots (A) in the first round and to both plots (A and B) in the second round of grazing. This type of transmission cannot be the main cause of the infection observed because the calf and the donkey grazed these plots when the soil was relatively dry.

Our study shows that cows can transmit the virus to seedbeds and infect a considerable number of seedlings. Field surveys made in 2002 confirmed that seedbed infection could result in dramatic effects (data not shown). Due to the late start of the rainfall in 2002, cattle often had free access to early-sown seedbeds and could frequent them for some time before the seedlings were transplanted. Some crops appeared severely or completely infected using the seedlings from those seedbeds, which were frequented one or more times by cattle during the excessively long periods before the seedlings were transplanted.

In the experiments in which the spread by cattle in partially infected fields was studied, the infection increased from 9 to $36 \%$ in field 1 . The percentage of infected plants rose from 4 to $21 \%$ in the infected plots in field 2, whereas $16 \%$ of the plants became infected in 43 out of the original 52 healthy plots. No virus was introduced

Table 5. Number of insects trapped in two stubble fields 15,30 , and 45 days post grazing by cattle

\begin{tabular}{lcc}
\hline & \multicolumn{2}{c}{ No. of insects trapped } \\
\cline { 2 - 3 } Insect family & Field $\mathbf{1}$ & Field 2 \\
\hline Heteroptera & 1 & 5 \\
Diptera & 69 & 82 \\
Hymenoptera & 1 & 0 \\
Coleoptera & 4 & 14 \\
Homoptera & 7 & 20 \\
Orthoptera & 1 & 5 \\
Odonate & 0 & 2 \\
Arachnidae (spiders) & 7 & 13 \\
\hline
\end{tabular}


in nine of the original healthy plots in field 2. These results show that cattle also can transmit the virus after harvest. This spread was considerably lower in the stubble fields than in the experimental plots wherein the calf was given access to young rice plants. The size of the spread will depend on the development of the stubble after harvest.

Cattle herds roam the stubble fields during the off season and enhance the number of infected plants. The infected stubble form a source from which the virus may be released after plowing in the soil and surface water and may infect the next crop. The size of this inoculum will depend on different factors, such as the number of infected stubble, the time at which the regrowth starts, and the development of the regrowth, which depends largely on the rainfall before plowing and the period between plowing and transplanting. Plowing of a well-developed and heavily infected regrowth just before transplanting may result in the release of a large inoculum supply, which can infect the seedlings when transplanted.

Like cattle, rats also may enhance the number of infected plants and the virus load in stubble fields by their feeding activities. However, of more importance may be their return to dryer places to feed on the seed as soon as the seedbeds are sown and on the new seedlings when they have access to the germinating seedlings.

\section{ACKNOWLEDGMENTS}

We thank Directoraat Generaal Internationale Samenwerking (DGIS) and Netherlands Management Co-operation Programme (NMCP) for their financial support

\section{LITERATURE CITED}

1. Abo, M. E., Sy, A. A., and Alegbejo, M. D. 1998. Rice yellow mottle virus. RYMV in Af- rica: evolution, distribution, economic significance on sustainable rice production and management. J. Sustain. Agric. 11:85-111.

2. Attere, A. F., and Fatokun, C. A. 1983. Reaction of Oryza glaberrima accessions to rice yellow mottle virus. Plant Dis. 67:420-421.

3. Awoderu, V. A. 1991. The rice yellow mottle virus situation in West Africa. J. Basic Microbiol. 31:91-99.

4. Bakker, W. 1970. Rice yellow mottle virus a mechanically transmissible virus disease of rice in Kenya. Neth. J. Plant Pathol. 76:53-63.

5. Bakker, W. 1974. Characterisation and ecological aspects of rice yellow mottle virus in Kenya. Ph.D. thesis. Agricultural University, Wageningen, the Netherlands.

6. Banwo, O. O., Makundi, R. H., Abdallah, R. R., and Mbapila, J. C. 2001. Identification of vectors of Rice yellow mottle virus in Tanzania. Arch. Phytopathol. Pflanzenschutz 33:395-403.

7. Banwo, O. O., Makundi, R. H., Abdallah, R. R., and Mbapila, J. C. 2002. Bionomics and importance of two species of Chaetocnema in rice yellow mottle virus transmission in lowland rice in Tanzania. Phytoparasitica 30:96104.

8. Clark, M. F., and Adams, A. N. 1977. Characteristics of the microplate method of enzyme-linked immunosorbent assay for the detection of plant viruses. J. Gen. Virol. 34:475-483

9. Fauquet, C. M., and Thouvenel, J. C. 1977. Isolation of rice yellow mottle virus in Ivory Coast. Plant Dis. Rep. 61:443-446.

10. Ferris, D. G., Jones, R. A. C., and Wroth, J. M. 1996. Determining the effectiveness of resistance to subterranean clover mottle sobemovirus in different genotypes of subterranean clover in the field using the grazing animal as virus vector. Ann. Appl. Biol. 128:303-315.

11. Fomba, S. N. 1988. Screening for resistance to rice yellow mottle virus in some rice cultivars in Sierra Leone. Plant Dis. 72:641642.

12. Fomba, S. N. 1990. Rice yellow mottle virus on swamp rice in Guinea. Int. Rice Res. Newsl. 15:21.

13. Heinrichs, E. A., Sy, A. A., Akator, S. K., and Oyediran, I. 1997. Seasonal occurrence of rice yellow mottle virus in Côte d'Ivoire. Int. J.
Pest Manage. 43:291-297.

14. International Rice Research Institute. 1988 Standard Evaluation System for Rice. 3rd ed IRRI, Los Batros, Philippines.

15. John, V. T., Thottappilly, G., and Gibbons, J. W. 1985. Varietal reaction to rice yellow mottle virus disease. FAO Plant Prot. Bull. 33:109-111.

16. Konate, G., Traore, O., and Goulibaly, M. M. 1997. Characterization of rice yellow mottle virus isolates in Sudano-Sahelian areas. Arch. Virol. 142:1117-1124.

17. McKirdy, S. J., Jones, R. A. C., and Sivasithamparam, K. 1998. Determining the effectiveness of grazing and trampling by livestock in transmitting white clover mosaic and subterranean clover mottle virus. Ann. Appl. Biol. 132:91-105.

18. Ngon, Y. M. 1989. Detection sérologique du virus de la panachure jaune du riz et de trois viroses du mays. DEA de Sciences Agronomiques. Acad. de Montpellier, Université des Sciences et Techniques du Languedoc, Montpellier, France.

19. Oevering, P. 1996. A Study on the Epidemiology of Rice Yellow Mottle Virus in the Niono Region. M.Sc. thesis. "Office du Niger", Niono, Mali.

20. Peters, D., Sarra, S., Oevering, P., Idoe, Y., and Guindo, D. 1999. Spread of rice yellow mottle sobemovirus from observations and experimental results. Proc. VIIth Int. Plant Virus Epidemiol. Symp. Aguadulce, Almeria, Spain.

21. Reckhaus, P. M., and Andriamasinthseheno, H. E. 1997. Rice yellow mottle virus in Madagascar and its epidemiology in northwest of the island. Z. Pflanzenkrankh. Pflanzenschutz 104:289-295.

22. Rossel, H. W., Thottapilly, G., and Buddenhagen, I. W. 1982. Occurrence of rice yellow mottle virus in two important rice growing areas of Nigeria. FAO Plant Prot. Bull. 30:137139.

23. Sarra, S. 1998. Quelques aspects écologiques du virus de la panachure jaune du riz en zone Soudano-sahelienne. DEA thesis. University Ouagadougou. Burkina-Faso.

24. Taylor, D. R., Fofie, A. S., and Suma, M. 1990. Natural infection of rice yellow mottle virus disease (RYM) on rice in Sierra Leone. Int. Rice Res. Newsl. 15:19. 